\author{
Marius Turda \\ Oxford Brookes University, Oxford
}

\title{
ROMANIAN EUGENIC SUB-CULTURE AND THE ALLURE OF BIOPOLITICS, 1918-39*
}

\begin{abstract}
By the late 1920s a considerable body of eugenic literature in Romanian, Hungarian and German had been produced in Romania, illustrating the growing importance afforded to science and evolutionary theories of human improvement in this country. Engaging with this literature, this article investigates the emergence of a Romanian sub-culture in Transylvania and the Banat, sanctioned through eugenics and biopolitics, and promoted by cultural associations and prominent intellectuals and politicians. In so doing, this article contributes not only to a new appraisal of the relationship between ethnic minorities and majorities in interwar Romania, but also to a new understanding of the ways in which eugenics and biopolitics were harnessed to Romanian narratives of nation-building during the interwar period.
\end{abstract}

Keywords: sub-culture, eugenics, biopolitics, interwar Romania, Transylvania and the Banat

Romanian historians of medicine have been slow to acknowledge the importance of eugenics to the development of Romanian social and medical sciences, as well as its imprint on Romanian political culture, more generally, between 1918 and $1945 .{ }^{1}$ Moreover, the significance

* The research and writing of this article was made possible by the AHRC grant (Ref. AH/J00507X/1) and the Wellcome Trust grant (Ref. 096580/Z/11). I am grateful to Răzvan Pârâianu for his comments, criticism and encouragement. I also want to thank the anonymous reviewers for their suggestions.

${ }^{1}$ One of them, Gheorghe Brătescu, for instance, describes Romanian eugenics as "frail", lacking any substantial endorsement from the scientific and political establishment. See Gh. Brătescu, Către sănătatea perfectă. O istorie a utopismului medical (București, 1999), 406-11. It is only with the publication of Maria Bucur, Eugenics and Modernization in Interwar Romania (Pittsburgh, 2002), and its subsequent translation into Romanian in 2005, that the subject has received a fair treatment. For a recent overview of Romanian eugenics, see Marius Turda, 'Romania', 
of other eugenic movements than the Romanian one is only now getting the recognition it deserves. ${ }^{2}$ Much empirical work remains to be done on the broader implications, impact and effectiveness of eugenic ideas outside the national capital, Bucharest, during the interwar period, for instance. ${ }^{3}$ In practical terms, this means exploring the country's specific regional contexts, its multi-ethnic environments, and local contingencies within which eugenic ideas and practices were developed during this period. Moreover, such historical inquiry requires that consideration should also be given to the role of various cultural associations and journals that took a lead in promoting eugenics as well as to the public responsibility of eugenicists who assumed political offices or university positions, thus influencing several generations of students and, in effect, changing the scientific discourse about the nation in interwar Romania.

These features lend to the history of eugenics and biopolitics in interwar Romania a certain conceptual difficulty. The interwar period reflects the overlapping and tangled relations between Romania's ethnic communities, not only in terms of shared cultural and political history, but also in terms of common eugenic predicaments. In its own way, each ethnic group voiced similar concerns about biological decline, and the need for demographic growth and racial renewal. Tellingly, they all enthusiastically embraced eugenics as a protective strategy meant to safeguard the future of the nation, and, to some extent, shared a common foundation. However, following the incorporation of Transylvania ${ }^{4}$ and the Banat into Romania after the First World War, local Hungarian and German eugenic movements were reconfigured $^{5}$; this time, however, as minority eugenic sub-cultures,

in idem (ed.), The History of Eugenics in East-Central Europe, 1900-1945: Sources and Commentaries (London, 2015), 271-361.

2 See Tudor Georgescu, The Eugenic Fortress: The Transylvanian Saxon Experiment in Interwar Romania (Budapest, 2016).

${ }^{3}$ Fortunately, Cluj, Transylvania's main city, has not been ignored. See Zsuzsa Bokor, Testtörténetek. A nemzet és a nemi betegségek medikalizálása a két világháború közötti Kolozsváron (Kolozsvár, 2013).

${ }^{4}$ For the sake of brevity, I will hereafter use the term 'Transylvania' to refer not only to Transylvania proper, but also to Maramureș and Crișana.

${ }^{5}$ Hungarian and German eugenic movements were well established before 1918, whilst the Romanian one only became institutionalised during the 1920s. For Hungarian eugenics before 1918, see Marius Turda, Eugenics and Nation in Early 20th Century Hungary (Basingstoke, 2014). 
developing defensive strategies to protect these ethnic communities from an increasingly assertive Romanian eugenic movement.

By the time it was adopted by educated Romanians in Transylvania and the Banat, during the early 1920s, eugenics was fit to serve their regional nationalist purposes. ${ }^{6}$ The relationship between eugenics and nationalism was symbiotic in that they shared the same interest in the future of the Romanian nation. For instance, Transylvania and the Banat were to become Romanian; this notion Romanian eugenicists held in firm belief. In many ways they proposed a new vision of the Romanian national community. In practical terms, moreover, their ambition encountered major obstacles, not least demographic. During the interwar period, the Romanians were the largest ethnic group in the country, but they did not constitute the majority in every city and village in Transylvania and the Banat; indeed there were regions, such as the Székelyföld, where there were only few Romanians villages. Moreover, urban elites in Transylvania and the Banat were predominantly Hungarian, German and Jewish. Furthermore, there were areas, particularly in the Banat, in which the Romanian population was in decline, giving a renewed impetus to a more generalised sentiment of demographic imbalance in the region. ${ }^{7}$ That the Hungarian and German elites in interwar Romania fought against political centralization, de-nationalisation, and the loss of their civil privileges, whilst experiencing increased political radicalisation (particularly after 1933) is well known; ${ }^{8}$ less discussed is that they also

${ }^{6}$ To some extent, the idea of a recurrent conflict along eugenic lines fits into the broader interpretation of interwar Romania, which suggests that the country was characterised by conflicting nationalisms and ethnic struggles. See Irina Livezeanu, Cultural Politics in Greater Romania: Regionalism, Nation, Building \& Ethnic Struggle, 1918-1930 (Ithaca, NY, 1995).

${ }^{7}$ Romania's ethnic diversity can be underlined further by reference to cultural, religious and linguistic variations amongst the minorities themselves. For instance, long standing differences in custom, dialect and religion existed between the Zipsers of Maramureș, the Saxons of Transylvania, and the Swabians of the Banat (all of German extraction); and, of course, differences existed between the Hungarians and the Szeklers in Transylvania and the Csángós in Moldova. Moreover, the Saxons were Protestant, whilst the Swabians were Catholic, and a similar religious distinction existed amongst the Hungarians. Finally, most Romanians in Transylvania and Maramureș were Greek-Catholic, whilst those in the Banat, like the rest of the country, were Orthodox.

${ }^{8}$ For the Hungarian minority, see: Gábor Egry, 'Phantom Menaces? Ethnic Categorization, Loyalty and State Security in Interwar Romania', Hungarian 
fought against the decline of their demographic vitality, and thus of their economic potential and social dominance. ${ }^{9}$ As a result, during the interwar period, Hungarian and German eugenic sub-cultures worked tirelessly to protect their demographic position in cities and villages in Transylvania and the Banat, whereas the Romanians were on a biopolitical offensive, striving to occupy those places and ideally re-populate them. Whilst demographic growth seemed to be the only thing that counted, it brought with it additional eugenic concerns, most notably the alleged detrimental impact of mixed marriages. ${ }^{10}$

When discussing eugenics and biopolitics in interwar Romania, therefore, one needs to be aware of not only the interaction between the Romanian majority and the ethnic minorities, but also of intraminority and intra-majority relations, and of attempts to inculcate them with a sense of togetherness across geographical divisions. ${ }^{11}$ It is now known that the ethnic relations between Romania's various ethnic communities were always in flux, and that the boundaries between them less rigid than official political and nationalist litera-

Historical Review, iii, 3 (2014), 650-82; Stefano Bottoni, 'National Projects, Regional Identities, Everyday Compromises: Szeklerland in Greater Romania (1919-1940)', Hungarian Historical Review, ii, 3 (2013), 477-511; for the German minority, see Mariana Hausleitner, Die Donauschwaben 1868-1948: Ihre Rolle im rumänischen und serbischen Banat (Stuttgart, 2014). In the case of the Germans in Romania, more broadly, the obsession remains with the post-1933 period. For the latest contribution see the special issue of Spiegelungen. Zeitschrift für deutsche Kultur und Geschichte Südosteuropas (2016), edited by Florian Kührer-Wielach and entitled Rumäniendeutsche und Nationalsozialismus.

${ }^{9}$ For the case of Bukovina, see Mariana Hausleitner, Die Rumänisierung der Bukowina: die Durchsetzung des nationalstaatlichen Anspruchs Grossrumäniens 1918-1944 (München, 2001).

${ }^{10}$ Eugenic literature on the subject seems alarmist but we should not paint the picture too black. In Transylvania, it is clear, however, that the practice of mixed marriages was rather common among the Romanians during the 1920s. For instance, in the report for the council of the Eparhia Orthodoxa Română a Vadului, Feleacului, Geoagiului și Clujului published in May 1925 (but covering also the year 1924) we find out that out of 2,784 religious marriages recorded in the bishopric 450 were mixed. See 'Dela Sinod', Renașterea, iii (31 May 1925), 4.

${ }^{11}$ See: R. Chris Davis, 'Nationalizing the Moldavian Csangos: Clericalism and Ethnic Mobilization in World War II Romania and Hungary', in Robert Pyrah and Marius Turda (eds.), Re-Contextualising East Central European History: Nation, Culture and Minority Groups (Oxford, 2010), 74-88; Balázs A. Szelényi, 'From Minority to Übermensch: The Social Roots of Ethnic Conflict in the German Diaspora of Hungary, Romania and Slovakia', Past and Present, cxcvi, 1 (2007), 215-51. 
ture would make us believe. ${ }^{12}$ As is shown by recent scholarship, even a cursory look at the life of ethnic communities from the newly integrated territories, at least during the early 1920s, reflects less the nationalising obsession of the Romanian state and more the elasticity of identity, the fusion between social, religious and ethnic loyalties, and the cultural syncretism, characterising the main urban centres. ${ }^{13}$

There is, however, an additional factor that must be considered, namely the role of local Romanian elites. It was they who planned and carried out the successful incorporation of Transylvania and the Banat into the new state and formulated the subsequent appropriation of its multi-ethnic space. ${ }^{14}$ And it is these elites that created a new Romanian national culture in Transylvania and the Banat after 1918 that not only differed from the previous one in terms of political goals, but also in terms of its national agenda. ${ }^{15}$ Less discussed in the scholarship is the fact that a number of sub-cultures emerged, almost simultaneously: one that was administrative, political and institutional; ${ }^{16}$

12 It suffices to read memoirs or interviews with members of the ethnic minorities about their childhood during the interwar period. See, for example, Várdy Péter, 'Az életben van, amit az ember nem tesz... és tesz': Beszélgetések Tóth Imrével (Budapest, 2004). Imre Tóth (b. Róth) (1921-2010) was a Jewish-Hungarian philosopher and mathematician who was born and grew up in Satu Mare/Szatmarnémeti.

${ }^{13}$ Gábor Egry, 'Navigating the Straits. Changing Borders, Changing Rules and Practices of Ethnicity and Loyalty in Romania after 1918', Hungarian Historical Review, ii, 3 (2013), 449-76.

${ }^{14}$ According to one of the architects of this historical process, Romul Boilă (1881-1946), it was due to the Romanian political elites from Transylvania and the Banat that "this epochal change [the break-up of these regions from Hungary] occurred within the time span of one year, without atrocities or loss of human life, without the disruption of public life, without cruelty, and without the abuse of power. This would forever be our proudest achievement before the civilised world." In Romul Boilă, 'Consiliul Dirigent', în Transilvania, Banatul, Crișana, Maramureșul, 1918-1928, i (București, 1929), 101.

${ }^{15}$ For Romanian political culture in Austria-Hungary before 1918 see Keith Hitchins, A Nation Affirmed: The Romanian National Movement in Transylvania, 1860-1914 (Bucharest, 1999).

${ }^{16}$ In administrative and political terms, Romanian sub-culture in Transylvania and the Banat was short-lived; it only lasted two years between 1918 and 1920, when Consiliul Dirigent (Governing or Ruling Council) which carried out the transfer of political and administrative power from the Hungarian authorities to the Romanian National Assembly (Marele Sfat Național), elected in December 
one that was literary and intellectual; ${ }^{17}$ and, finally, the one discussed in this article, that defined itself as eugenic and biopolitical. Interwar Romania not only provides examples of well-articulated regional eugenic sub-cultures but, more importantly, of eugenic sub-cultures, such as the Romanian one, which ultimately became the dominant eugenic culture of the entire country.

The Romanian eugenic sub-culture, as it developed in Transylvania and the Banat after 1918, positioned itself not only in relation to competing Hungarian and German eugenic sub-cultures, but also to the broader Romanian national project, out of which it carved out its own identity. The existence of the Romanian nation may have been proclaimed by Romanian National Assembly, at its gathering in Alba-Iulia on 1 December 1918, but it still had to be mapped out physically. To achieve this goal, Romanian eugenic sub-culture in Transylvania and the Banat assumed a double task: firstly, to identify who the Romanians were, and, secondly, to provide a strategy to educate them about their biological importance to the future of the nation. As I have addressed some of the issues pertaining to the racial classification of the Romanians elsewhere, ${ }^{18}$ it is the latter aspect that will be explored in this article.

1918 to represent the interests of the Romanian population in the territories of Maramureș, Transylvania, Crișana and the Banat, was officially dissolved and these territories came under the jurisdiction of the Romanian government in Bucharest. See Gheorghe Iancu, The Ruling Council: The Integration of Transylvania into Romania: 1918-1920, trans. by Magda Wachter (Cluj, 1995).

17 This sub-culture is known as Transylvanism, a literary movement popular especially amongst Hungarian and German intellectuals during the 1930s, based on spiritual synchronicity and geographical interdependence. As the Hungarian ethnographer Károly Kós (1883-1977) put it, the peoples of Transylvania "lived their own lives, building their own social and cultural institutions side by side, not mingling with each other, but not really bothering each other; rarely crossing each other's path, yet in touch with each other, learning from each other, influencing each other." - idem, Transylvania. An Outline of its Cultural History (Budapest, 1989), 81 [the original Hungarian text was published in 1934]. For an excellent discussion of Transylvanism, see Gábor Egry, Az Erdélyiség Szineváltozásai. Kisérlet az Erdélyi Párt ideológiájának és identitáspolitikájának elemzésére 1940-1944 (Budapest, 2008).

${ }^{18}$ Marius Turda, 'In Search of Racial Types: Soldiers and the Anthropological Mapping of the Romanian Nation, 1914-1944', Patterns of Prejudice, xlvii, 1 (2013), 1-21. 


\section{I \\ TERMINOLOGY}

At this point, a few observations about terminology are necessary. The concept of sub-culture that I am using here embodies and represents a particular constellation of meanings put forward by certain communities, not only to self-identify and describe themselves in racial, linguistic or cultural terms, but also in order to accomplish a certain identity building agenda. ${ }^{19}$ A sub-culture consists of a specific description of itself, which is created and then widely disseminated by the school, the church, and so on; in a word by its own educated elites. This self-identification is further reproduced through newspapers and journals, and newly founded research institutes and universities.

More often than not, sub-cultures thrive in spite of state-led projects of national homogenisation. ${ }^{20}$ They promote a sense of multiple belonging (local, regional, national) and of in-betweenness, which draws sustenance from both majority and minority cultures, but, in effect, differ from both. ${ }^{21}$ In fact, it is the acceptance or rejection of the national state that define many of the sub-cultures that sprung up in Europe after the First World War. ${ }^{22}$ Yet, the fixation on the nation, so characteristic of the interwar period, did not exclude more focused interest in local and regional identities. ${ }^{23}$ In Transylvania and the

${ }^{19}$ I am reminded here of the definition of culture put forward by the American anthropologist Clifford Geertz (1926-2006), in his classic The Interpretation of Cultures (New York, 1973). For Geertz, following Max Weber, "man is an animal suspended in webs of significance he himself has spun." - ibidem, 5 .

${ }^{20}$ A brief comparative overview is offered in Marius Turda, "Minorities and Eugenic Subcultures in East-Central Europe', Acta Hist. Med. Stom. Pharm. Med. Vet., xxxiv, 1 (2015), 8-17.

${ }^{21}$ For a similar attempt to reconceptualise the concept of ethnic sub-cultures but in a different national context in East-Central Europe, see Robert Pyrah and Jan Fellerer, 'Redefining 'Sub-Culture': A New Lens for Understanding Hybrid Cultural Identities in East-Central Europe with a Case Study from early 20th Century L'viv-Lwów-Lemberg', Nations and Nationalism, xxi, 4 (2015), 700-20.

${ }^{22}$ I highlight the end of the First Wold War here in order to make a more general point about the temporality of certain sub-cultures in East-Central Europe, which exist only within specific historical periods and which, in fact, are determined by major historical events, such as the dismemberment of the Austro-Hungarian Monarchy in 1918, the dissolution of Czechoslovakia in 1938 and of Yugoslavia in 1941, the creation of the communist East after 1945, and so on.

${ }^{23}$ As argued in another context by Thomas Kühne, 'Imagined Regions: The Construction of Traditional, Democratic and other Identities', in James Retallack 
Banat, specifically, sub-cultures were predominantly determined by the internal ethnic dynamic, multilingualism, multi-confessionalism and interculturality that characterised these regions for centuries. ${ }^{24}$ They existed in a spatial synchronicity (the same regions) and within a temporal simultaneity (the interwar period), but they were not identical. Also, it is important to emphasise the fact that, contrary to what the term may suggest, sub-cultures in Transylvania and the Banat were not in a subaltern position vis-à-vis each other, or, indeed, vis-à-vis the state-enforced Romanian national politics. ${ }^{25}$

In more specific terms, I argue that eugenic sub-cultures, defined as integrative scientific narratives of human improvement, framed within a process of continuous negotiation, definition and redefinition of the national body, can help us make sense of the biological dimensions of identity, still within a cultural context, but mindful of health, hygiene, sexuality, fertility and so on. These eugenic subcultures, therefore, existed as scientific strategies for coping with new political realities after 1918, and they also offered a distinctive solution to specific biological and social problems characterising these communities, such as ethnic mixing, depopulation, family protection, child and youth welfare, and so on.

On one hand, in using the concept of sub-culture to describe the Romanian eugenic movement in Transylvania and the Banat, I hope to show just how unstable and in constant need of reaffirmation the Romanian national project was during the interwar period. This was, as is known, a troubled time for the Romanian state, as it tried to secure its territorial achievements, whilst, at the same time, striving to build a stable social order that could withstand internal ethnic tensions and discordant political visions. On the other hand, I hope to demonstrate

(ed.), Saxony in German History: Culture, Society and Politics, 1830-1933 (Ann Arbor, 2000), 51-62. See also Alon Confino, The Nation as a Local Metaphor: Württemberg, Imperial Germany, and National Memory, 1871-1918 (Chapel Hill, 1997).

${ }^{24}$ Also, I should point out that I am not applying here Michel Foucault's argument about "subjugated knowledge" or Antonio Gramsci's idea of "subalternity". For the former, see Michel Foucault, Power/Knowledge: Selected Interviews and Other Writings, 1971-1977 (New York, 1980); for the latter, see Antonio Gramsci, The Prison Notebooks, 2 vols., trans. by Joseph A. Buttigieg (New York, 1975).

${ }^{25}$ It is not my intention to dwell here on the meaning of 'subaltern', which now enjoys widespread usage in post-colonial studies. See, from a vast literature, Rosalind C. Morris, Can the Subaltern Speak? Reflections on the History of an Idea (New York, 2010). 
that a Romanian eugenic sub-culture in Transylvania and the Banat was, in fact, needed in order to assert control over the multiplicity of identity projects that threatened to destabilise, both politically and nationally, the new Romanian state. ${ }^{26}$ In this respect, eugenics aspired to offer the much-needed physical protection of the nation's biological frontiers, whilst endowing it with its own conception of biopolitics. Both underlined the intrinsic Romanianness of these regions, not just symbolically as nineteenth century nationalism had done it, but practically in terms of living individuals, families and communities. At its core was the blurring of boundaries between the individual body and the collective body of the nation, reinforced by a perpetual invocation of a generic collective identity, transcending time and space. During the 1920s and 1930s, it was this Transylvanian Romanian eugenic vision that was vigorously promoted as a unifying biopolitical strategy.

\section{II \\ A NEW BEGINNING}

1919 marked the beginning of organised Romanian eugenic research, not only in Transylvania ${ }^{27}$ but, in fact, in the entire country. ${ }^{28}$ This emerged at the same time as various research agendas were being

${ }^{26}$ See Florian Kührer-Wielach, Siebenbürgen ohne Siebenbürger? Zentralstaatliche Integration und politischer Regionalismus nach dem Ersten Weltkrieg (München, 2014).

${ }^{27}$ The Saxon physician, Heinrich Siegmund (1867-1937), published the first eugenic text in Transylvania, as early as 1901. See Heinrich Siegmund, Zur sächsischen Rassenhygiene (Hermannstadt, 1901). For a discussion of Siegmund's ideas, see Georgescu, The Eugenic Fortress and Timo Hagen, 'Die Führung der Evangelischen Landeskirche A.B. in Rumänien im Umgang mit Opposition und völkischem Gedankengut zwischen 1919 und der Etablierung des Nationalsozialismus 1933', in Kührer-Wielach, Rumäniendeutsche und Nationalsozialismus, 21-6.

${ }^{28}$ The earliest record we have of a public discussion of eugenics in Romania is from 1906. See Gheorghe Marinescu, 'Progresele și tendințele medicinei moderne', Academia Română, Discursuri de recepție, 28 (10/23 March 1906), 3-34, esp. 33-4. Marinescu (1863-1938) was a prominent Romanian neurologist and president of the Romanian Society of Eugenics and Heredity (1935-8). The First International Eugenics Congress, held in London in 1912, was reported in medical journals in Bucharest. See Constantin Andronescu, 'Eugenia', Higiena, i, 21 (1912), 2. By 1914, Romanian newspapers in Transylvania such as Românul are trying to familiarise their readers with topics such as eugenic sterilisation. See Românul (9/22 Jan. 1914). The first book on eugenics was published in Romania in 1921, authored by physician Ioan I. Manliu (1886-?), and entitled Crâmpeie de eugenie şi igienă socială 
professionalised and specialised. ${ }^{29}$ In that year, the first Romanian university, bearing the impressive name of Universitatea Daciei Superioare (University of Dacia Superior) ${ }^{30}$ was established in Cluj, and it included a Faculty of Medicine. Its Dean was Iuliu Hațieganu (1885-1959), ${ }^{31}$ who was also entrusted with the directorship of the city's renowned Medical Clinic (Belgyógyászati Klinika). In the same year, Iuliu Moldovan (1882-1966), a Romanian physician from the county of Mureş in Transylvania, founded the Institute of Hygiene and Social Hygiene (Institutul de Igienă şi Igienă Socială) affiliated to the university, where, beginning with the academic year 1921-2, he taught courses on eugenics and biopolitics. ${ }^{32}$ Moldovan's pursuit of a theory of eugenics tailored for the Romanian nation ${ }^{33}$ was part of

(București, 1921). The first doctoral dissertation in medicine focussing on eugenics, and how it applied to Romania, was submitted in 1925 at the Faculty of Medicine in Bucharest. It was entitled Degenerare și Eugenică cu o incercare de aplicare in România. Its author, Herman Fischgold (1899-1982), left Romania in 1929, and became one of France's most important radiologists.

${ }^{29}$ Scholars have studied the social composition and intellectual preferences of educated elites in Transylvania before and after 1918, focusing on enrolments in institutions of higher education. This is an important aspect of the broader discussion about the scientific communities in the region. See, for example, Viktor Karády and Lucian Năstasă, The Medical Faculty of the University of Kolozsvár/Cluj and its students (1872-1918) (Budapest and Cluj, 2004).

${ }^{30}$ It was renamed King Ferdinand I University in 1927.

${ }^{31}$ Iuliu Hațieganu, Rector of the University in Cluj and member of the Romanian Academy, was one of the most prominent Romanian physicians of the interwar period. His medical research focussed mostly on tuberculosis. He was also very active in the public and political life in Transylvania and Romania. See Florea Marin, Iuliu Hațieganu: monografie (Cluj, 1999).

${ }^{32}$ Moldovan's own professional life and role as a scientist were not confined to his writings on eugenics and biopolitics. He was and is well-known in the history of immunology for his research on the mononuclear phagocyte system (also called the reticuloendothelial system or macrophage system) in immune reactions. In 1923 Moldovan discovered an antianaphylactic peptide secreted by the reticuloendothelial system which he termed 'Reticulina $\mathrm{M}$ ', as a tribute to the Russian immunologist Élie Metchnikoff (1845-1916). The drug with the same name, 'Reticulina M', was introduced experimentally in 1939, proving successful in the prevention and treatment of various infections, rheumatism, endocarditis and arterial hypertension. See: Petru Râmneanțu, Iuliu Moldovan (1882-1966). Viața, realizările şi epoca sa (București, 1977); Marius Turda, 'Iuliu Moldovan', in Turda (ed.), The History of Eugenics, 296-9.

${ }^{33}$ We do not exactly know when and how Moldovan became acquainted with eugenics; for obvious reasons, he did not dwell on the subject when he wrote his 
a broader process of re-nationalisation that the self-appointed Romanian authorities carried out in Transylvania and the Banat under the transitional government called the Governing Council of Transylvania (Consiliul Dirigent al Transilvaniei) based in Sibiu between 1918 and 1920, when it was dissolved by the central government in Bucharest. As institution-builder, university professor, government minister, educator and president of ASTRA (Transylvanian Association for Romanian Literature and the Culture of the Romanian People), Moldovan's contribution to the development of Romanian social and biomedical research during the interwar period was matched only by that of sociologist Dimitrie Gusti (1880-1955). ${ }^{34}$

In the 1920s, old and new problems facing Transylvania and the Banat, and of Greater Romania, more generally, were reconfigured in terms of social and national health. ${ }^{35}$ Medical programmes introduced during this period reflected an engagement with modern ideas of social hygiene, health care and public assistance. ${ }^{36}$ The call was for a new society, a new man, and a new Romanian, and the medical profession answered it most earnestly. "The physician - Iuliu Hațieganu wrote in 1925 - is the most useful and important social agent of the

memoirs after the release from the Sighet prison in 1955. See Iuliu Moldovan, Amintiri şi reflexiuni (București, 1996). It is, however, very likely that he became familiar with eugenics in Prague and Vienna, where he studied medicine in the years before the First World War. We also know that, as a physician in the AustroHungarian Army, he attended the meeting of the Medical Section of the Hungarian Fraternal Military Association (A Magyarországi Bajtársi Szövetség Orvosi Szakosztálya) in Budapest between 21 and 23 September 1918. The last day of the conference was dedicated to racial hygiene and population policy, and on this occasion Moldovan listened, and possibly met, important Austrian, German, and Hungarian eugenicists such as Max von Gruber and Géza Hoffmann. See Marius Turda, Eugenics and Nation in Early 20th Century Hungary (Basingstoke, 2014), 221-4.

${ }^{34}$ Unfortunately, I cannot offer here a proper discussion of Gusti's numerous institutional achievements and of his seminal role in the emergence of Romanian sociology. For a good overview of his impact on Romanian academic and university life, see Omagiu profesorului D. Gusti (Bucureşti, 1936).

${ }^{35}$ A good overview of the main medical debates in pre-1914 Romania is provided in Constantin Bărbulescu România medicilor. Medici, țărani și igienă rurală în România de la 1860 la 1910 (București, 2015).

${ }^{36}$ One should mention in this context the important funding and training received by Romanian hygienists and eugenicists from the Rockefeller Foundation. See Petru Râmneanțu, 'Fundația Rockefeller', Buletin eugenic şi biopolitic, xvi (1945), $120-43$. 
state." 37 It was not only the physician, however, who underwent a biopolitical conversion; medicine itself was seen as a "national science' serving the state's mission to improve population's health. According to Aurel Voina (1896-1967), medicine, hygiene and eugenics were to be used as the progressive mediums through which to achieve the much-needed transformation of Romanian society. ${ }^{38}$ For all involved, this was no mere rhetoric but an experiment of civilization and culture, endorsed by Romanian intellectual and political elites across the ideological spectrum. ${ }^{39}$ Indeed, the creation of Greater Romania in 1918 offered new opportunities for Romanian physicians to plan and direct the future of their nation through social and medical policies built first into the country's emerging health and welfare system. ${ }^{40}$ Central to their theories was the idea that the Romanian nation's improvement was predicated not only upon intellectual enlightenment but also upon prevention and eradication of contagious diseases, modern sanitation and housing, hygiene education and, last but not least, the cultivation of awareness of the country's biological worth. ${ }^{41}$

Eugenics, in this context, was essentially seen as a progressive scientific and social movement that could provide much-needed assistance to local officials, regional organisations, churches and the central government. In the early 1920s, Odiseu Apostol's (1895-1980) attempt to popularise eugenics through local newspapers from Cluj such as Cultura Poporului ('People's Culture'), or Iuliu Moldovan's first articles on biopolitics published in Societatea de Mâine ('Tomorrow's Society') and Acțiunea Românească ('Romanian Action'), are characteristic of these early attempts to introduce the educated Romanian public in Transylvania to his interpretations of the nation

${ }^{37}$ Iuliu Hațieganu, 'Rolul social al medicului în opera de consolidare a statului național', Transilvania, liv (1925), 588. All translations from Romanian are mine unless otherwise indicated.

${ }^{38}$ Aurel Voina, 'Doi factori de progress: igiena şi eugenia', Societatea de mâine, i, 8 (1 June 1924), 183-4.

39 Vasile Pârvan, 'Universitatea națională a Daciei Superioare', Luceafărul, xiv (1919), 105-16.

${ }^{40}$ See Marius Turda, 'Gheorghe Banu's Theory of Rural Biology in the 1920s Romania', in Constantin Bărbulescu and Alin Ciupală (eds.), Medicine, Hygiene and Society from the Eighteenth to the Twentieth Centuries (Cluj-Napoca, 2012), 125-40.

${ }^{41}$ Aurel Voina, Eugenia şi igiena națiunii (Cluj, 1924). 
as a biological organism, in need of protection and betterment, and to his vision of the new Romanian state. ${ }^{42}$ Other physicians, such as Dominic Stanca (1892-1979), argued that eugenic education should already start in high school, and the future of the Romanian nation depended on it. ${ }^{43} \mathrm{He}$, as many others collaborating with Moldovan in Cluj, insisted that state, community and families should work together to create the circumstances necessary for the Romanian youth to flourish. ${ }^{44}$ Like elsewhere in Europe at the time, Romanian eugenicists were worried about social and biological degeneration, which they discussed sometime in relation to race, but mainly in terms of its impact on the nation..$^{45}$

This signified a shift in the production of knowledge about the nation regarding the importance of social research, in general and of eugenics, in particular, in making the experience of Romanian ethnicity in Transylvania and the Banat possible. A number of journals and associations were established during the 1920s, with the purpose to ensure the realization of this goal. ${ }^{46}$ For instance, Clujul Medical, the journal of the Faculty of Medicine, began its publication in 1920, whilst Viața Medicală ('Medical Life') appeared in Timişoara in 1925. Societatea de Mâine, mentioned earlier, was launched in 1924 in Cluj, followed in 1926 by Banatul ('The Banat') in Timişoara. Together with the prestigious Transilvania, edited and published by the Transylvanian Association for Romanian Literature and the Culture of the Romanian People (generally known as ASTRA) in Sibiu, these journals published regularly on eugenics and biopolitics. ${ }^{47}$ Eventually, in 1927, a specialised

${ }^{42}$ Dr. Apostol, 'Eugenia', Cultura poporului, iv (1924), 5; idem, 'Eugenia', Cultura poporului, v (1925), 4; Iuliu Moldovan, 'Un program biopolitic', Societatea de Mâine, i, 3 (27 April 1924), 69-70; idem, 'Sisteme politice și biopolitica', Acțiunea Românească, i (1924), 2-3.

${ }^{43}$ Dominic Stanca, O anchetă sanitară la un liceu (Cluj, 1924). See also Simion Mehedinți, Şcoala română şi capitalul biologic al poporului român (Cluj, 1927).

${ }^{44} \mathrm{~A}$ similar educational programme geared towards introducing the youth to the ideas of eugenics was already successfully carried out by the Saxon Lutheran church in their confessional schools.

${ }^{45}$ See Marius Turda and Aaron Gillette, Latin Eugenics in Comparative Perspective (London, 2014).

${ }^{46}$ For example, Asociația Culturală din Banat, established in Caransebeș in 1919.

${ }^{47}$ It was also during this period that Hungarian cultural journals in Cluj, such as Korunk and Pásztortüz, began publishing on eugenic topics, offering translations 
journal was established to this effect in Cluj, appropriately entitled Buletin eugenic şi biopolitic ('Eugenics and Biopolitical Bulletin'), which continually advocated and disseminated Moldovan's ideas, and the fieldwork research carried out by his students, collaborators and fellow eugenicists. ${ }^{48}$ This was Romania's first and most lasting eugenic journal (it was published, with a brief interruption between 1931 and 1933, until 1947). ${ }^{49}$

This work of popularization was paralleled by an equally committed attempt to institutionalize eugenics and biopolitics. As early as 1921, Moldovan submitted a proposal to the General Sanitary Inspectorate in Cluj, suggesting the establishment of a "faculty or academy of preventive biopolitics", in addition to "an institute of eugenics, dedicated to a historical, experimental and statistical study of the main traits of our race and of the principles to improve it." 50 It is interesting to note that also in 1921, Bucharest based physician Ioan I. Manliu (1886-?), influenced by American and German eugenic movements, proposed the creation of a Eugenics Bureau; the establishment of chairs of racial hygiene at every university in Romania; a yearly eugenic congress; and the foundation of a Museum of Hygiene and Eugenics - all with the purpose of promoting a healthy Romanian nation and race. ${ }^{51}$ What

from foreign eugenicists, or reporting on the work of Hungarian eugenicists across the border. For one such translation, see Eugen Fischer, 'A modern anthropológia problémái', Korunk, i (1926), 692-700. Specialised medical journals such as Erdélyi Orvosi Lap (Kolozsvár/Cluj), Praxis Medici (Temesvár/Timişoara), and Magyar Népegészségügyi Szemle (Marosvásárhely/Târgu Mureș) also occasionally published on eugenic topics. A very different situation characterised German publications in Transylvania and the Banat, which, as in the case of Medizinische Zeitschrift (Hermannstadt/Sibiu), published extensively on racial hygiene.

${ }^{48}$ Gheorghe Preda, 'Buletinul Eugenic şi Biopolitic al 'Astrei', Transilvania, lxvi (1935), 155-8.

${ }^{49}$ The other one, edited by eugenicist Gheorghe Banu (1889-1957) in Bucharest between 1931-44, was Revistă de Igienă Socială. Worth mentioning are also the short-lived Sănătatea publică, edited by Aurel Voina in 1927 in Bucharest. Other journals which published regularly on eugenic topics include: Progresul Social, Revista Institutului Social Banat-Crişana, Sociologie Românească, Revista de Medicină Legală, Mişcarea Medicală Română, Revista Sănătatea şi 'Viața Fericită', România Medicală.

${ }^{50}$ Iuliu Moldovan, 'Documente din trecut. Adresă şi proiect de lege privind înființarea unei Academii biopolitice. Inspectoratul general sanitar şi de ocrotire Cluj. No. 31628/921', Buletin eugenic şi biopolitic, ix, 11-12 (1938), 337.

${ }^{51}$ Manliu, Crâmpeie de eugenie, 39-42 and 78-80. 
Moldovan offered was not imitation of eugenic programmes elsewhere, but an innovative national eugenics, based on traditional Romanian nationalism, elements of social progress and historical continuity, which appealed to many sympathetic contemporaries. ${ }^{52}$ A Romanian eugenics was, in short, Moldovan's answer to a young nation-state searching for new foundations upon which to base individual and collective improvement. ${ }^{53}$

Various Romanian politicians from Transylvania seized upon Moldovan's ideas of eugenics and biopolitics to demonstrate the necessity for a state-controlled programme of national rejuvenation. ${ }^{54}$ They joined forces to publicly argue in favour of biopolitical ideas. A major step forward was the establishment in 1925 in Cluj of ASTRA's Medical and Biopolitical Section (Secția medicală şi biopolitică), affiliated to the Institute of Hygiene and Social Hygiene..$^{55}$ Iuliu Hațieganu was President, with Iuliu Moldovan as Vice-President and Aurel Voina as Secretary. ${ }^{56}$ This section, in turn, established a subsection on eugenics and biopolitics, and one on physical education. ${ }^{57}$

${ }^{52}$ As such, it echoes the idea put forward by English eugenicist Karl Pearson (1857-1936), namely: "Every nation has in certain sense its own study of eugenics, and what is true of one nation is not necessarily true of the second. ... Eugenics must from this aspect be essentially national". See Pearson, The Academic Aspect of the Science of National Eugenics (London, 1911), 4.

${ }^{53}$ Although he never mentioned other eugenicists, apart from Francis Galton, one cannot fail to notice Moldovan's similarity to other national eugenic projects in East-Central Europe, particularly the one developed by the Czech eugenicists during the late 1910s and early 1920s (národni eugenika). It is very likely that Moldovan had met some of them during his studies in Prague (1903-6). See, for example, Vladislav Růžička, Biologické základy eugeniky (Praha, 1923).

${ }^{54}$ See, for example, Alexandru Vaida-Voevod, 'Politica națională și capitalul biologic național', Buletin eugenic şi biopolitic, i, 5 (1927), 199-211. Vaida-Voevod (1872-1950) served three terms as a Prime Minister of Greater Romania (1919-20; 1932; and again in 1933).

55 The inaugural meeting of the Medical and Biopolitical Section took place on 1 November 1925 at the Medical Clinic. See L. Daniello, 'Activitatea Clinicii Medicale I pe terenul igienei sociale în cadrele "Secției medicale şi biopolitice a Astrei"', in Douăzeci de ani de activitate românească în Clinica Medicală I din Cluj, 1919-1940 (Sibiu, 1941), 231-6.

${ }^{56}$ Iuliu Hațieganu and Aurel Voina, 'ASTRA medicală şi biopolitică', Societatea de mâine, ii, 46-47 (15-22 Nov. 1925), 813-14. See also Bucur, Eugenics and Modernization, 126.

${ }^{57}$ Hațieganu also established Romania's first Medical Society of Sport and Physical Education (Societatea medicală de educație fizică şi sport) in 1930. 
In 1927, ASTRA's Feminist and Biopolitical Section, was formed, led by Maria B. Băiulescu (1860-1941), adding a much-needed women's contribution to the eugenic debates on the health of the national body. ${ }^{58}$

Gradually, ASTRA's entire cultural agenda became saturated with eugenic and biopolitical ideas. Already in 1926 at ASTRA's general meeting, held in the town of Zalău (Crișana), Moldovan proposed the adoption of biopolitics as ASTRA's dominant ideology. His suggestion was met with approval and eventually led to the creation of a new organisation, entitled Şoimii Carpaților (Carpathian Falcons) in 1929, with Hațieganu at its helm, whose main goal was the physical education of the Romanian youth. ${ }^{59}$ Finally, in terms of written propaganda, a book series devoted to eugenics, the so-called 'Biblioteca eugenică şi biopolitică' (Eugenic and Biopolitical Library), ${ }^{60}$ commenced publication in 1925; its first book being Iuliu Moldovan's Igiena națiunii: Eugenia.

Suffusing these Romanians journals, societies, and the entire collection of public lectures on eugenics and related themes was a confident faith in medicine, progress and science, a readiness to believe that a modern nation state required a healthy and numerous population. ${ }^{61}$ Some of ASTRA's leaders, such as Iuliu Hațieganu and Iuliu Moldovan, were most active in several of these overlapping networks, groups and sub-sections, acting at local, municipal,

58 'Secția femenină-biopolitică a 'ASTREI', Buletin Eugenic şi Biopolitic, ii (1928), $63-4$.

${ }^{59}$ T. Spârchez, 'Activitatea culturală în cadrul Asociațiunii "Astra": "Şoimii Carpaților”', in Douăzeci de ani de activitate românească, 237-46.

${ }^{60}$ Similar book series existed in Czechoslovakia ('Eugenická knihovna') and Poland ('Biblioteka Eugeniczna') during the interwar period.

${ }^{61}$ The first public event organised by the Medical and Biopolitical Section was in 1927, namely a series of lectures by some of Romania's most known academics and politicians. Speakers included biologist Emil Racoviță (1868-1947), Dimitre Gusti (mentioned above), philosopher Constantin Rădulescu-Motru (1868-1957) and geographer Simion Mehedinți (1868-1962). ASTRA's eugenic propaganda needs, however, to be seen within the context of a biological determinism which became increasingly influential in the 1920s, in Romania and elsewhere in EastCentral Europe, and which stressed the biological factors that determined national identities. See Maciej Górny, 'Bitterly Triumphant: The Biologisation of National Character in the Twentieth Century East-Central Europe', Acta Poloniae Historica, cxi (2015), 29-56. 
and regional levels. Although the degree of their actual involvement varied over time, ${ }^{62}$ their push for eugenics, biopolitics and physical education remained constant until the end of the Second World War. The practical application of eugenics, and its underlying nationalist ideology, which I described elsewhere as the biologisation of national belonging, ${ }^{63}$ were intertwined and mutually supportive. To understand it better, a brief discussion of Moldovan's ideas of eugenics and biopolitics is now necessary.

\section{III}

\section{EUGENICS AND BIOPOLITICS}

A eugenic sub-culture emerged in Transylvania and the Banat between 1918 and 1939, and produced a diverse array of meanings associated with it. It rested on two concepts: the hygiene of the nation, understood as the eugenic theory behind the biological health of the nation, and biopolitics, interpreted as its practical application to social realities. Both were Moldovan's own terms, which he believed reflected his theories of social and biological improvement better than other terms such as Francis Galton's eugenics and Alfred Ploetz's racial hygiene.

In 1921, in his course for the first generation of students at the Institute of Hygiene and Social Hygiene, Moldovan defined eugenics as "the science dealing with the study of the nation's biology and pathology", whilst biopolitics was "the science of government, based on the unalterable laws of biology, investigating all aspects of life

62 Both Moldovan and Haţieganu held ministerial positions in interwar Romania. Moldovan was General Hygiene Inspector for Transylvania (1920-5) and General Secretary of the Ministry of Health and Social Welfare (1928-30), and as such succeeded in introducing a new sanitary law in 1930. Hațieganu was Minister of Health in 1931. In 1938, they joined the Superior Council, a committee of experts meant to assist King Carol II. Finally, in 1943 Moldovan was appointed President of the Commission for the Promotion and Protection of the Biological Capital of the Nation, entrusted with preparing a comprehensive account of the health of the population, to be submitted to Marshal Ion Antonescu, together with concrete quantitative and qualitative eugenic proposals.

${ }^{63}$ I first proposed this term in an article I published in 2007. See Marius Turda, 'The Nation as Object: Race, Blood, and Biopolitics in Interwar Romania', Slavic Review, lxvi (2007), 413-41. A more elaborate and comparative perspective was offered in my Modernism and Eugenics (Basingstoke, 2010). 
in a state from the vantage point of health and eugenics". ${ }^{64}$ It was, however, in his Igiena națiunii: Eugenia, the book he published in 1925, that his theory of eugenics received its definitive form. First and foremost, he placed eugenics within the matrix of ethnic Romanian nationalism, defined not by language and culture but by race. "I feel Romanian - he claimed - not because I live in my country, not only because I speak Romanian." What mattered was the racial awareness of one's unique position within a historical narrative that connected the past to the present. "I am Romanian - he continued - because I believe that in my veins runs a blood different to that of other people and, through my ancestors, [also runs] a drop of the blood of those who had contributed to the creation of my nation. This blood relation, this biological relation of race ('legatura biologică de sânge'), makes us Romanians, as it did with our ancestors." 65

The individual really mattered only if his or her national community mattered, and that was what eugenics professed to achieve: not only the mere protection of the nation but, more importantly, its continuous existence. The goal, therefore was "to keep our nation's hereditary patrimony ('patrimoniu ereditar') untainted, ... to guarantee its demographic growth, to ensure the victory in the competition with other nations, and finally, to organise our living space in such a way that each individual is able to develop and make the most of his/her innate qualities in the interest of the nation." ${ }^{66}$ In this context, the national state was described as the embodiment of agencies and institutions concerned with the population's health; whilst the nation was seen and valued as biologically adaptable, capable of being improved through eugenic technologies of social and biological selection.

The family was placed at the centre of this theory of national eugenics, and Moldovan envisioned measures to protect it from both social and biological predicaments. But to make it possible to instil in the individual a biological responsibility towards the nation,

${ }^{64}$ Iuliu Moldovan, 'Dare de seamă asupra activității Institutului de Igienă şi Igienă Socială în anul școlar 1921-1922', in Anuarul Universității din Cluj pe anul şcolar 1921-22 (Cluj, 1923), 71 and 73.

${ }^{65}$ Idem, 'The Hygiene of the Nation: Eugenics', trans. by Marius Turda, in Turda (ed.), The History of Eugenics, 300.

${ }^{66}$ Ibidem. I draw here on my chapter one Romanian eugenics published in Turda (ed), The History of Eugenics, 275-6. 
a specialised institution was needed, Moldovan believed. An 'Institute for National Biology and Eugenics' (Institut pentru biologia şi igiena națiunii), he recommended, "must be established immediately and provided with the latest technology, as it should study our biological past and recommend ways and methods for our national biopolitical action". ${ }^{67}$

By characterising eugenics as simultaneously national and progressive, Moldovan offered an idealized version of public health reform, whilst at the same time providing instructions on how to achieve the biological betterment of the Romanians. This required above all, the adoption of a national politics centred on eugenic principles. He developed this idea further in his second book, published in 1926, and aptly entitled Biopolitica. ${ }^{68}$

Moldovan's book was certainly the first one in Europe or elsewhere, to put together eugenics and biopolitics into a totalizing philosophy of national improvement. ${ }^{69}$ Maria Bucur appropriately described this book as "a manifesto that called for a total eugenic state based on biological principles" ${ }^{70}$ It was, indeed, intended to add weight and scientific credibility to the emerging civilising mission of the Romanian state in Transylvania and the Banat. As Moldovan noted, what was required of the Romanian state was "to guarantee to the fullest [degree] possible the biological prosperity of its citizens." ${ }^{\text {"1 }}$ Economic wealth and cultural progress whilst not discarded entirely were simply eclipsed by the biological aspects of human relations and identity. It was based on the assumption that the laws of evolution and heredity governed the life of individuals. The corresponding political vision for such reality was what Moldovan termed as biopolitics.

67 Ibidem, 301.

${ }^{68}$ This book was the second to be published in ASTRA's book series on eugenics and biopolitics. For a comprehensive discussion, see Bucur, Eugenics and Modernization, 78-110.

${ }^{69}$ The first discussion of biopolitics I am aware of was attempted in 1911 in the modernist journal The New Age in reference to policies of public health, reproduction and social welfare. It also indicated a strong connection between these policies and the state, with the latter seen as the only instrument capable of implementing those policies. See G.W. Harris, 'Bio-Politics', The New Age: A Weekly Review of Politics, Literature, and Art, x, 9 (28 Dec. 1911), 197.

${ }^{70}$ Bucur, Eugenics and Modernization, 83.

${ }^{71}$ Iuliu Moldovan, 'Biopolitics', trans. by Răzvan Pârâianu, in Turda (ed.), The History of Eugenics, 302. 
In his words, it was "a general programme, based on human capital and aimed exclusively at its biological prosperity". ${ }^{72}$

As expected, Moldovan argued in favour of appropriate family policies as a necessary means of eugenic improvement, primarily the encouragement of beneficial unions between healthy Romanians. In keeping with this view, the "reproductive family, on whose purity our biological future depends" was placed "at the centre of biopolitics." In terms of eugenic selection, Moldovan opposed "the brutal elimination of defectives" but conceded that the way forward was to exclude them completely from reproduction. Given this emphasis on control and management, it comes as no surprise that Moldovan subsumed "economic and cultural development" to "individual and collective biological development" deemed as the only long-lasting foundation of the biopolitical state. ${ }^{74}$

It is easy to identify the eugenic and biopolitical elements that have been combined here. First, it is the importance of the family, then the traditional link between reproduction and the future of the nation, and, finally, the no less characteristic connection between social and biological worth. To be sure, Moldovan adapted the eugenic ideal to reflect his country's specific historical and demographic context. What should unite the Romanians, he believed, was not any political ideology acting in the name of the nation, but a new synthesis of nationalist and eugenic ideals, one which Moldovan termed biopolitics. It was this new scientific ethos that underlined the envisioned biological improvement of the Romanian society.

By introducing biopolitics into Romanian public discourse, Moldovan did not just formulate a eugenic interpretation of local realities in Transylvania, he also invested it with a specific historical mission: to preserve and improve the racial qualities of the nation. Biopolitics thus operated through investigations of biological processes regulating the triadic relationship between individual, nation and state. Ultimately, Moldovan insisted, the general eugenic goal was that biopolitics became the state ideology in Romania.

These two books, Igiena națiunii: Eugenia and Biopolitica, constituted the programmatic texts of the eugenic sub-culture in Transylvania and

\footnotetext{
72 Ibidem.

${ }^{73}$ Ibidem.

${ }^{74}$ Ibidem, 303.
} 
the Banat, and as such informed not only the activities of ASTRA's Medical and Biopolitical Section but also the subsequent eugenic literature produced by Moldovan's students and collaborators, ${ }^{75}$ and even by some Hungarian eugenicists. ${ }^{76}$ Moldovan was, unmistakably, the leader in the broad and far-reaching process of national transformation that placed eugenics at its centre and that began in 1918. With this in mind, we can now turn to a discussion of some of the specific ways in which biopolitics became entangled with a broader agenda of national education and progress in Transylvania and the Banat. To this effect, it is ASTRA that we must consider again, as this association was incontestably the principal source of the dissemination of eugenics and biopolitics to the general public.

\section{IV \\ ASTRA'S STRATEGIC ROLE}

By the late 1920s, a Romanian eugenic sub-culture was fully established in Transylvania and the Banat. Its connections to the medical profession was through institutions in Cluj, such as the Faculty of Medicine, the Institute of Hygiene and Social Hygiene, and the Medical Clinic. Through ASTRA, however, it reached widely, into every Romanian town and village in Transylvania and the Banat, ultimately aspiring to become effective in the entire country. ${ }^{77}$

${ }^{75}$ For example, Gheorghe Popovici, 'Biopolitica, puericultura şi schimbarea de sistem în conducerea statului', Societatea de mâine, v, 22-24 (1928), 443-4.

${ }^{76}$ One example is provided by Dénes László, a Hungarian physician from Nagybánya/Baia Mare (a town in the county of Satu-Mare), who contrasted Francis Galton's definition of eugenics, to that of Iuliu Moldovan, and favouring the latter, as it applied better to local realities. See László Dénes, 'Fajbiológia és sterilizálás', Korunk, xii (1933), 917-20.

77 ASTRA branches were established in other regions of Romania, such as ASTRA Basarabeană (in Bessarabia) and ASTRA Dobrogeană (in Dobrudja), both in 1927. It should not be assumed that this was necessarily a straightforward process. In the Banat, for instance, ASTRA's intention to set up a regional branch was met with reticence by other cultural associations and by ASTRA's main competitor in the region, Institutul Social Banat-Crișana (established in 1932). ASTRA Bănățeană was established only in 1937 with Sabin Evuțianu (1889-1977) as President. Eugenicist and demographer Petru Râmneanțu (1896-1975) led the section on demography and ethnopolitics, whilst physician Alexandru Miletici was entrusted with the section on medicine and biopolitics. 
Historians of interwar Romania will, no doubt, continue to write about the centralising policies of the Romanian state but, as I argue here, in order to understand the articulations of eugenic sub-cultures at the time, attention must also be paid to individuals, non-governmental organisations and various cultural associations. In Transylvania and the Banat it was ASTRA that provided the institutional network essential to the successful interaction between cultural and political elites, and the majority of the population. ${ }^{78}$

In 1932, Moldovan became ASTRA's President. From that moment onwards the eugenic sub-culture in Transylvania and the Banat became one of ASTRA's main projects, regarded as a source of regenerative nationalism and scientific progress, and aimed at ensuring Romanian dominance in these regions. Illustrating this growing emphasis on eugenics, in 1934, the Medical and Biopolitical Section was renamed Eugenics and Biopolitical Section with Moldovan as President and eugenicist Iordache Făcăoaru (1897-1984), one of his disciples, as Secretary. ${ }^{79}$ As Maria Bucur aptly suggested, Romanian eugenicists turned ASTRA "into the largest nongovernmental Romanian organisation with a coherent eugenic program." ${ }^{80}$ With branches across Maramureș, Transylvania, Crișana and the Banat, ASTRA's true affinity, and the focus of the eugenic sub-culture it cultivated, was with the peasantry. Like other Romanian eugenicists, Moldovan valued the peasantry as the nation's embodiment of racial fertility strength. ${ }^{81}$ To augment the peasants' sense of eugenic responsibility was difficult, however. Romanian rural communities during the interwar period, for all the intellectual debates in journals and newspapers, and books written

${ }^{78}$ For a historical overview, see Pamfil Matei, Asociațiunea Transilvană pentru Literatura Română şi Cultura Poporului Român (ASTRA) şi rolul ei în cultura naţională (1861-1950) (Cluj, 1986). ASTRA is an exemplary case, similar perhaps only to the Transylvanian Saxon associations, it terms of its commitment to eugenics and biopolitics. For a discussion of ASTRA in relation to the German (Verein für Siebenbürgische Landeskunde) and Hungarian (Erdélyi Múzeum Egyesület) cultural organisations in Transylvania before 1918, see Borbála Zsuzsanna Török, Exploring Transylvania: Geographies of Knowledge and Entangled Histories in a Multiethnic Province, 1790-1918 (Leiden, 2016).

${ }^{79}$ It would change the name again in 1943 to Biopolitical Section (Secția biopolitică), with Moldovan as President. See Turda, 'Romania', 298.

${ }^{80}$ Bucur, Eugenics and Modernization, 23.

${ }^{81}$ See the work of another prominent Romanian eugenicist, Gheorghe Banu (1889-1957), who published extensively on the "health of the Romanian people". 
about them, remained heavily conservative, suspicious of all external influences, and overwhelmingly homogenous, both ethnically and religiously. It took time to embrace ASTRA's eugenic pastoralism, but eventually, and with the help of the presidents of the local branches, ${ }^{82}$ Moldovan succeeded in promoting its own version of national betterment, at every village and communal level across Transylvania and the Banat. ${ }^{83}$ Between June 1930 and June 1931, for example, the Eugenics and Biopolitical Section organised over 150 conferences in villages across Transylvania, ${ }^{84}$ but in 1935 alone, it organised 315 conferences, including the showing of 72 films. ${ }^{85}$ The implication was that the theories of eugenics and biopolitics needed to be enacted and demonstrated in order to convince the population of their importance.

Furthermore, new regional journals, such as Progres și Cultură (Progress and Culture), established in 1933 by a group of Romanian intellectuals in the predominantly Hungarian town of Târgu Mureș (Marosvásárhely) testify to the growing acceptance of eugenics outside the main university centres such as Cluj and Timişoara. In 1934, none other than the future historian of Transylvania, Vasile Netea (1912-89) penned an article entitled 'Eugenia şi problemele ei' (Eugenics and Its Concerns), in which he re-affirmed the biopolitical importance of the nation and family for his country's social and biological improvement. "Through eugenic measures - Netea argued - we can strengthen and authenticate the nation's biological and intellectual values, enhancing their creative and defiance power" .86

${ }^{82}$ Two such presidents are worth mentioning: one from Maramureș, physician Vasile Ilea (1891-1969), Director of the Psychiatric Hospital in Sighet and Prefect of Maramureș county (1932-3); and the other from Mureș, physician Eugen Virgil Nicoară (1893-1985), Director of the Hospital in Reghin and Prefect of Mureș county (1938).

${ }^{83}$ For example, in 1931 ASTRA established a 'peasant school' in Sighet (the capital of Maramureș county), the first of its kind in Romania, where adult peasants were taught diverse subjects, including history, geography, hygiene and physical education. See Vasile Ilea, 'Prima școală țărănească din România Mare', Transilvania, lxxiii (1942), 851-63.

84 'Darea de seamă despre activitatea Secției medicale și biopolitice a "Astrei", dela 30 iunie 1930 - 30 iunie 1931', Transilvania, lxii (1931), 36-7.

${ }^{85}$ Gheorghe Preda, Activitatea 'ASTREI' în 25 ani de la Unire, 1918-1943 (Sibiu, 1944), 122. See also Turda, 'Romania', 276.

${ }^{86}$ Vasile Netea, 'Eugenia şi problemele ei', Progres şi cultură, ii, 4 (1 April 1934), 23. 
From the position of his authority as ASTRA's President, Moldovan reiterated his commitment to eugenics and biopolitics at all general meetings, held every year across cities and towns across Transylvania. At one held in Satu-Mare in 1935, for instance, he declared: "the biopolitical conception of life should become the compass of our thinking and action. It places the man not the environment, the family not the individual, the nation not the society at the centre of our preoccupations". ${ }^{87}$ It was, however, in his opening speech to ASTRA's general meeting, held in Timişoara in 1937, that Moldovan detailed the full scope of his biopolitical vision. Within a generalized decline in the quality and quantity of population, there was a pressing need, Moldovan asserted, for a re-evaluation of the physical fitness of the Romanian nation, or lack of it. Not enough, Moldovan believed, was done to cultivate "our interest for our ethnic heritage and ethnic purpose" 88 in Transylvania and the Banat. Tellingly, he invoked here the prominent Romanian nationalist (and an eugenicist avant la lettre) Aurel C. Popovici (1863-1917), who under the influence of racial thinking and Social Darwinism viewed the nation as a community held together by ties of blood with its own peculiar character and destiny. ${ }^{89}$

It was not only an educational campaign that was needed to awaken the population's interest in their own ethnic history but organised practical research. The following research centres were outlined: a "centre for the study of our ethnic history, which to elucidate our origins" and, equally important, "the internal and external factors which determine our quantitative and qualitative development"; then, a "centre for archaeological research" and one for "anthropological research into the racial structure of our nation"; followed by a "centre for ethno-biological research" and a "centre for ethno-geographical research". Next, it was a "centre for bio-sociology", together with a "centre for ethnography and popular art" and "a centre for juridical customs, originating in our ancestors' wisdom but needed to guide social and economic life according to ethnic laws".

${ }^{87}$ Quoted in Preda, Activitatea 'ASTREI', 30.

${ }^{88}$ Iuliu Moldovan, "Cuvânt de deschidere a Adunării Generale a "Astrei" din Timişoara', Transilvania, lxviii (1937), 368.

${ }^{89}$ I have discussed Popovici's nationalist Darwinism in Marius Turda, The Idea of National Superiority in Central Europe, 1880-1918 (New York, 2004). 
Furthermore, Moldovan proposed a "centre for Romanian ethics and philosophy, to study the social order and the conception of life specific to our people" and a "centre for ethno-psychology, to study Romanian soul". Returning to more palpable aspects of research, he suggested a "centre of ethnopathology, to study the health problems affecting the nation" and an "institute of demography". All of this research into the social, racial, medical, cultural, and religious aspects of the Romanian nation was to be brought together into a "large institute of ethno-eugenics and biopolitics" whose crucial role was to centralise research and then produce the "knowledge of our ethnic realities" needed for state politics. ${ }^{90}$ Equally ambitious was Moldovan's suggestion that, once formed in each university centre in Romania, these institutes of research would then join forces to establish a faculty of biopolitics, where students and teachers alike could receive proper eugenic training, so that they could pass it on further down along the education system, into primary and secondary school. ${ }^{91}$

As he was in Timişoara, Moldovan also underlined the Banat's remarkable "ethnic heritage", and encouraged the local elites to join their forces in "making this region the proud example of our Romanian improvement." 92 This was as much an endorsement of the ASTRA's local branch in the Banat, ASTRA Bănățeană, which was established earlier that year, and a confirmation that Moldovan's conception of national eugenics and biopolitics was by then assimilated by regional institutions and organisations. ASTRA Bănățeană, for instance, had one section on Demography and Ethnopolitics and one on Medicine and Biopolitics, each with a president, vice-president and a secretary. The latter section, for instance, had 18 founding members, but it considered as 'corresponding members' all physicians active in the Banat, both in rural and urban hospitals and clinics. Not surprisingly then that one of the main goals was "to create among the [Romanian] families in the Banat a new mentality, based on eugenics and biopolitics." 93

As these and other examples suggest, by mid-1930s, eugenics and biopolitics emerged as true measures of the ASTRA's programme

90 Moldovan, 'Cuvânt de deschidere', 368-9.

91 Ibidem, 340.

92 Ibidem, 372.

93 'ASTRA Bănățeană', Luceafărul, iii (1937) [special issue dedicated to the Regional ASTRA Bănățeană], 123-4. 
for national renewal in Transylvania and the Banat. On one level, this was certainly due to Moldovan's persuasive personality, his institutional skills and the intellectual consistency of his argument. That other prominent members of ASTRA and recognised public intellectuals such as Iuliu Hațieganu also promoted similar ideas, particularly in the field of physical education and youth sport, contributed significantly to the wide dissemination of eugenic ideals of health, physical fitness and improvement. On another level, much of this success can be attributed to Romanian eugenic subculture in Transylvania and the Banat being situated at the intersection of various priorities related to the creation of a healthy and numerous Romanian nation during the interwar period. As such, the self-propelled biopolitical responsibility for current and future generations of Romanians that this sub-culture typified was, ultimately, the perfect expression of nation-building agenda whose aim was to use the regional context as a template for a country-wide political transformation.

\section{$\mathrm{V}$ \\ CONCLUSIONS}

By early 1940, biopolitics, both as concept and ideology, had come to represent in Romania the dominant synthesis of eugenic reflections about the social, cultural and biological improvement of the nation..$^{94}$ To be sure, the outbreak of the Second World War in 1939 and the territorial losses in the following year ${ }^{95}$ contributed significantly to this transformation. In this context, Moldovan's ideas of biopolitics dovetailed into broader nationalist tendencies of the new regime, instituted after King Carol II's abdication in September 1940. The new Romanian national politics was predicated upon totalizing sociocultural responses to a number of perceived biological problems allegedly threatening the ethnic fabric of the Romanian national

${ }^{94}$ I discussed the development of eugenics and biopolitics in early 1940s elsewhere. See Marius Turda, 'Controlling the National Body: Ideas of Racial Purification in Romania, 1918-1944', in Christian Promitzer, Sevasti Trubeta, and Marius Turda (eds.), Health, Hygiene and Eugenics in Southeastern Europe to 1945 (Budapest, 2011), 325-50.

${ }^{95}$ In 1940, Romania lost Northern Bukovina, Bessarabia, Northern Transylvania and southern Dobrudja to the Soviet Union, Hungary and Bulgaria, respectively. 
community. ${ }^{96}$ Not surprisingly, then, in August 1940 Romania's Minister of Justice, Ioan V. Gruia (1895-1952), declared on the occasion of the introduction of new anti-Semitic racial laws in Romania: "We consider Romanian blood as a fundamental element in the founding of the Nation." 97 In 1941, Mihai Antonescu (1904-46), Deputy Prime Minister and Minister of Foreign Affairs, also confirmed the biological foundation of a new Romanian state, subscribing to the biopolitical axiom shared by Romanian eugenicists: "The individual is nothing; the nation is everything". Romania had finally become a functional biological state, the guardian of the biological qualities of the nation, ${ }^{98}$ which was to be fortified not merely under the banner of a cultural and political ideology, but through a new synthesis of biological and eugenic morality.

Within debates over the political culture of wartime Romania (and of course its contribution to the Holocaust), an investigation of Romania's distinct regional eugenic movements provokes us to rethink historiographic traditions applied to East Central Europe more generally, and to Romania in particular. Of these two are most persistent: the dominant role of the nation-state, as a force in shaping cultural and historical identities; and the subordinate role of ethnic minorities and regions in this process. What I proposed here was a revision of these historiographic traditions, and of some of the assumptions underpinning them.

To some extent, the importance of the Romanian eugenic subculture in Transylvania and the Banat during the interwar period derived from ASTRA's capacity to elaborate a Romanian collective identity in need of eugenic protection and biopolitical improvement. ${ }^{99}$

${ }^{96}$ See also Vladimir Solonari, Purifying the Nation: Population Exchange and Ethnic Cleansing in Nazi-Allied Romania (Washington, 2010).

${ }^{97}$ Ioan V. Gruia, 'Expunere de motive la decretul lege nr. 2650/1940 privitor la reglementarea situației juridice a evreilor din România', Monitorul Official, 183 (9 Aug. 1940), 1. See also Marius Turda, 'Controlling the National Body: Ideas of Racial Purification in Romania, 1918-1944', in Christian Promitzer, Sevasti Trubeta and Marius Turda (eds.), Health, Hygiene and Eugenics in Southeastern Europe to 1945 (Budapest, 2011), 325-50.

${ }^{98}$ Mihai A. Antonescu, 'Principiile nouei reforme a Statului Român', Societatea de mâine, xviii (1941), 85-6.

${ }^{99}$ It is also important to consider the limitations of this category and of the conceptual questions raised by its use, and here I should like to thank the participants to the international conference 'Identities In-Between: East-Central 
As documented here, this eugenic sub-culture existed and functioned almost exclusively within ASTRA's ambitious and wide-ranging nationbuilding agenda. ${ }^{100}$ As reconstruction plans took shape during the early 1940s, including the transfer of populations between Romania and her neighbouring countries, alongside the military expansion in the East, eugenic definitions of national identity and the desirability of population control gained ascendancy. Some elements of the interwar eugenic sub-culture survived in the Banat during the war period, ${ }^{101}$ but its main proponents now eagerly embraced the idea of the homogeneous ethnic state. ${ }^{102}$

The final transformation of Romanian eugenic subculture into the official national culture occurred in 1943 with the creation of Commission for the Promotion and Protection of the Biological Capital of the Nation in Bucharest, with Moldovan as President. It seemed that Moldovan's long lasting goal to create a eugenic and biopolitical institute in Romania was finally within reach. Indeed, the Commission discussed the creation of an Institute of Ethno-Racial Biology (Institut de Biologie Etnorasială), composed of five sections: human genetics; bioanthropology; biopolitics and euthenics; and, finally, an office dealing with ethnic talents. These five sections, in turn, were divided into over twenty sub-sections, including heredo-pathology, serology, biotypology, demography, negative eugenics, migration and so on. As a reflection of the new political realities, the Commission proposed that the institute bears the name of Marshal Ion Antonescu.

Europe, c. 1900-present', held at Wolfson College Oxford between 12-13 September 2016, for their comments on an earlier formulation of this topic.

${ }^{100}$ It is impossible, of course, to ignore the anti-centralist aspects of ASTRA's biopolitical ideology. Whilst identifying the need for biological rejuvenation as a prerequisite for the entire Romanian nation, ASTRA's leaders such as I. Moldovan, Gh. Preda, I. Hațieganu, and others also emphasised the regional individuality and importance of Transylvania and the Banat within Romania. These individuals shared a common belief in the inherent value of the Romanian element in these provinces, and often opposed the political culture of Bucharest. Whilst it is worth noting that the regional issue, the so-called 'Transylvanian Question' possessed enormous mobilising power for Romanian and Hungarian national politics, I do not deal with it here. For a recent discussion see Holly Case, Between States. The Transylvanian Question and the European Idea during World War II (Stanford, 2009).

${ }^{101}$ E. Pocrean, 'Metode de eugenie, aplicabile în Banat', Revista Institutului Social Banat-Crişana, xi (1943), 13-42.

102 Iuliu Moldovan, Statul etnic (Sibiu, 1943). 
More importantly, for our discussion here, the proposed institute was described as the pinnacle of more than twenty years of eugenic and biopolitical work in Romania, initiated in Cluj by Iuliu Moldovan and his disciples. To this effect, in January 1944, the Commission proposed a Law for the Protection of the Family (Decret Lege pentru ocrotirea familiei), which officialised Moldovan's main eugenic belief: "the family as the life foundation of the Romanian nation and state". The Law required prenuptial medical certification, and the introduction of additional eugenic measures to protect the family, as well the introduction of compulsory sterilisation for those with mental and physical hereditary diseases. ${ }^{103}$

The end of the war and the political changes that followed prevented both the Institute of Ethno-Racial Biology and the Law for the Protection of the Family from becoming reality. Yet this did not terminate the flow of ideas of national betterment that Moldovan and other Transylvanian Romanian eugenicists advocated since the 1920s. During the communist period eugenic and biopolitical ideas began to coalesce again, and ultimately materialised in a particular form of national politics, whose causes and origins we can now understand better, but whose impact and significance for twentieth century Romania remains to be determined.

\section{SELECTED BIBLIOGRAPHY}

Bokor Zsuzsa, Testtörténetek. A nemzet és a nemi betegségek medikalizálása a két világháború közötti Kolozsváron (Kolozsvár, 2013).

Bucur Maria, Eugenics and Modernization in Interwar Romania (Pittsburgh, 2002).

Georgescu Tudor, The Eugenic Fortress: The Transylvanian Saxon Experiment in Interwar Romania (Budapest, 2016).

Iancu Gheorghe, The Ruling Council: The Integration of Transylvania into Romania: 1918-1920, trans. by Magda Wachter (Cluj, 1995).

Livezeanu Irina, Cultural Politics in Greater Romania: Regionalism, Nation, Building \& Ethnic Struggle, 1918-1930 (Ithaca, NY, 1995).

Matei Pamfil, Asociaţiunea Transilvană pentru Literatura Română şi Cultura Poporului Român (ASTRA) şi rolul ei în cultura națională (1861-1950) (Cluj, 1986).

Moldovan Iuliu, Biopolitica (Cluj 1926).

Moldovan Iuliu, Igiena națiunii: Eugenia (Cluj, 1925).

Moldovan Iuliu, Statul ethnic (Sibiu, 1943).

103 Arhivele Naționale ale Romaniei [The National Archives of Romania] Bucharest, Fond Nicolae Caranfil, no. fond. 765. 
Preda Gh., Activitatea 'ASTREI' în 25 ani de la Unire, 1918-1943 (Sibiu, 1944).

Turda Marius (ed.), The History of Eugenics in East-Central Europe, 1900-1945: Sources and Commentaries (London, 2015).

Turda Marius and Gillette Aaron, Latin Eugenics in Comparative Perspective (London, 2014).

Turda Marius, 'Controlling the National Body: Ideas of Racial Purification in Romania, 1918-1944', in Christian Promitzer, Sevasti Trubeta, and Marius Turda (eds.), Health, Hygiene and Eugenics in Southeastern Europe to 1945 (Budapest, 2011), 325-50.

Turda Marius, 'Gheorghe Banu's Theory of Rural Biology in the 1920s Romania', in Constantin Barbulescu and Alin Ciupală (eds.), Medicine, Hygiene and Society from the Eighteenth to the Twentieth Centuries (Cluj-Napoca, 2012), 125-40.

Turda Marius, Modernism and Eugenics (Basingstoke, 2010).

Turda Marius 'The Nation as Object: Race, Blood, and Biopolitics in Interwar Romania', Slavic Review, lxvi (2007), 413-41.

Voina Aurel, Eugenia şi igiena națiunii (Cluj, 1924).

Marius Turda - 20th century history and history of medicine, professor and director of the Centre for Medical Humanities at the Oxford Brookes University; e-mail: mturda@brookes.ac.uk 